doi: 10.15503.jecs2021.2.539.549

\title{
SPIRITUALITY AND IRRATIONAL BELIEFS OF MOVEMENT ACTIVITIES IN SLOVAKS AND CZECHS
}

\author{
IVANA TOMANOVÁ ČERGEŤOVÁ
}

College of Applied Psychology

Akademická 409, 411 55, Terezín, Czech Republic

\&

MARTINO - Institute of Society and Development, Slovak Republic

Galvaniho 25D, 821 04, Bratislava, Slovak Republic

E-mail address: cergetova.ivana@gmail.com

ORCID: https://orcid.org/0000-0001-7750-0634

\section{PATRIK MATURKANIČ}

College of Applied Psychology

Akademická 409, 411 55, Terezín, Czech Republic

E-mail address: maturkanic@vsaps.cz

ORCID: https://orcid.org/0000-0002-1087-3847

\section{L'UBOMÍR HLAD}

Department of Religious Studies

Faculty of Arts, Constantine the Philosopher University in Nitra

Hodžova 1, 94974 Nitra, Slovak Republic

E-mail address: 1hlad@ukf.sk

ORCID: https://orcid.org/0000-0003-1690-0057

\section{YULIA NICKOLAEVNA BIRYUKOVA}

Russian language department

Medical Institute

Peoples' Friendship University of Russia (RUDN University)

Miklukho-Maklaya 6, 117198 Moscow, Russia

E-mail address: yu.birukova@gmail.com

ORCID: https://orcid.org/0000-0002-5977-4081

\section{JOSÉ GARCIA MARTÍN}

University of Granada, Department of Sociology

Faculty of Political Sciences and Sociology

Calle Rector López Argüeta s/n, 18001 Granada, Spain

E-mail address: jgarciamartin@ugr.es

ORCID: https://orcid.org/0000-0001-7401-0613 


\section{ABSTRACT}

Aim. The present study is focused on exploring of the relationship between spirituality and irrational beliefs particularly in relation to movement activities in Slovakia and Czechia, i.e., helplessness, idealisation, perfectionism, external vulnerability, and negative expectation.

Concept. Our research has been focused on the investigation, comparison, and correlation between the level of spirituality and irrational beliefs depending on the frequency of sport activities.

Method. The research sample $(\mathrm{N}=469)$ consisted of Slovak and Czech health population aged 18-70 $(\mathrm{M}=41.97, \mathrm{SD}=13.14)$, of which $42.2 \%$ were men $(\mathrm{N}=198)$ and $57.8 \%$ were women $(\mathrm{N}=271)$. The level of spirituality was identified by means of the Expressions of Spiritual Inventory-Revised - ESI-R (MacDonald, 2000). The irrational beliefs were measured using the Scale of Irrational Beliefs (Kondáš \& Kordáčová, 2000).

Results. Research results confirmed the differences between the variables of spirituality and irrational beliefs based on the frequency of sports activities. Also, we confirmed the hypothesis of negative correlation between spirituality and irrational beliefs.

Conclusion. In our study, we focused on the correlations between irrational beliefs and spirituality in group of Slovak and Czech population. Based on our results we can draw several conclusions. Research results confirmed the differences between the variables of spirituality and irrational beliefs based on frequency of sports activities.

Key words: spirituality, irrational beliefs, movement activities

\section{INTRODUCTION}

$\mathrm{T}$ The people of post-communist Europe are looking for answers to what values and heritage they should intensively develop in the new global-pluralistic culture. Even Slovaks and Czech, after the fall of the forty-year ideology of communism, face a new world, foreign values and mentalities, unknown traditions and religions. Seeing their "differences" they themselves how to perceive and evaluate other religions; whether to understand and welcome them as guests or to condemn them forever as intruders (Tkáčová \& Al-Absiová et al., 2021). The fact is that religious pluralism in European countries has not achieved the expected weakening of faith. On the contrary, it turned out that it leads to an overall increase in religiosity. The surprising return of interest in religion was, on the other hand, reflected in its destiny - with the globalisation of the world grew the globalisation of religion and the activity of religious radicalism and fundamentalism, which led to a reaction in the structures of society but also in everyday interpersonal relationships (Tkáčová \& Pavlíková et al., 2021).

In the past, the spirituality and the irrationality were researched in the context of traumatic transition events of spiritual fundamentalism from Lee Kirkpatrick (Kirkpatrick et al., 1991), John Brent (1994), or Steven Hassan (1994). These studies point to a way of spiritual growth, which is associated with the abandonment of authoritarian and restrictive fundamentalism. In Slovakia, the topic of spirituality and irrationality was explored in the context of religious fundamentalism, subjective well-being and mental health (Halama et al., 2006), and this research points to the connection between fundamentalism and the 
surviving level of helplessness, idealisation, and neuroticism in the form of a compensatory coping mechanism, but this relationship was not confirmed at a statistically significant level. The previous research of fundamentalism and the attributes of irrational thinking also did not prove any clear evidence for any consistent relationship (Adamovová, 2005; Adamovová \& Kordačová, 2002). The irrationality in religion is often painted inter alia as a result of a sense of threat that is creating other forms of irrationality (Tkáčová, 2021), as a result of even temporary emotions (i.e., resentment) that can in unfavourable circumstances escalate into permanent emotions (i.e., permanent resentment), which is more difficult to alleviate (Kobylarek, 2016), and indirectly also by consequence of strong religious ideology and cultural roots of believers (Alaverdov, 2021) or religious exclusivism (Zalec \& Pavlíková, 2019). Primarily, the irrationality in religion is often highlighted through the emotional survival of a relationship with God, but it underestimates man's knowledge and voluntariness in faith (Suríková \& Slomińska, 2001). The connection between spirituality and irrationalism was mentioned only in psychology counselling of emotional, neurotic disorders as an opportunity to using of Ellis's rational-emotive therapy (Johnson, 1992; Lawrence, 1987; Nielsen, 1994). However, the religiosity can be independent of psychological disturbance (Rife \& Lester, 1997).

We lack research that would look at spirituality and irrationality in the context of a healthy population and in connection with physical activities and sport psychology. However, we can discover scientists' interest in the spirituality of movement (Haag \& Paas, 1992; Hoffman, 1999; MacDonald \& Kirk, 1999; Lacombe, 2001; Kahan, 2002; Parry et al., 2007; Preece \& Hess, 2006). The first studies in Slovakia and the Czech Republic began to appear in recent years (Bednář, 2009; Jirásek, 2008, 2010, 2011), with the most important publication Spirituality of physical activities (Hurych, 2013). Rational thinking and sport are the mostly connected to altruism in common studies (Ridley, 1996, 2000; Tomanová Čerget'ová, 2008). The first mentions of concept of spiritual health use the sense of non-religious spirituality, which basic characteristics are including the aspects of an authentic mode of existence, a relationship with other people, an understanding of the world of nature, the question of the purpose and meaning of life, and transition and transcendence (Jirásek, 2015).

The basic aspects of the humanistic mission of contemporary sport in our concept also include the spiritual part (Robinson \& Parry, 2013). Man realises philosophical thoughts about his own being, about other people, about the world, and about life during sports activities. High frequency of body density increases satisfaction with the quality of life also through spiritual comfort (Brod'áni, 2012). Physical activity and its sense can be perceived as a topic of spirituality of movement and its process of cultivation (Lišková \& Jirásek, 2013). The human body has a prodigious importance in the cycle of life and death - the body is simultaneously dying (extinct) and thus giving a chance for a new life. The body is also an image of one's disembodied (and also spiritual - in religious and secularised atheistic subcontent) qualities of a person, which 
we can observe in the motivation structure of athletes (Oborný, 2015). A person's spirituality also expresses the quality of the meaningfulness of his existence in the world, where human existence is, as opposed to despair as seen, for example, by Danish thinker Søren Kierkegaard. Kierkegaard (1813-1855), confronted with a hope to experience absolute freedom and salvation (Binetti et al., 2021; Pavlíková, 2016; more in receptions in Slovak and Czech: Králik 2013a,b; Králik \& Pavlíková 2013). The sphere of modern sport absorbed the spectrum of original anthropological elements (rivalry, aggression, tendency to dominance and victory) in an authentic connection with emotional and spiritual states during cultural development (Nemec, 2010). This idea leads us to research that would prove the connection between spirituality and sport as well as irrationality.

\section{METHODS}

\section{Research goal}

Our research has been focused on the investigation, comparison, and correlation between the level of spirituality and irrational beliefs depending on the frequency of sport activities. We have established two research questions: Are there differences in spirituality and irrational beliefs based on the frequency of sports activities? Are there relationships between the variables of spirituality and irrational beliefs? The present study aims to test the hypothesis of whether there is a negative relationship between spirituality and irrational beliefs oriented on helplessness, idealisation, perfectionism, external vulnerability, and negative expectation. We assume that the level of spirituality will decrease with the increasing frequency of sports activities, and in the case of irrational beliefs the opposite will be the case.

\section{Participants and study design}

The study sample consists of 469 participants $-42.2 \%$ men $(\mathrm{N}=198)$ and $57.8 \%$ women $(\mathrm{N}=271)$ - aged from 18 to 70 , with average age of $41.97 . \pm 13.14$ years. The whole study sample was composed of population in Slovakia and in Czechia with age over 18 years. From perspective of frequency in sports activities, the study sample consists of $10.4 \%$ non-athletes $(\mathrm{N}=49), 41.4 \%$ casual athletes $(\mathrm{N}=194), 23.5 \%$ regular athletes $(\mathrm{N}=110)$, and $24.7 \%$ professional athletes $(\mathrm{N}=116)$.

The data collection phase was conducted in December 2020. The measuring methods were distributed in online form using a snowball technique to collect data. Based on this technique, members of the required group were asked to contact potential respondents in close community who met the criteria of our research intention. All participants of the research agreed with the conditions of research and have been informed about consent complying with ethical and research standards. 


\section{Measuring instruments}

The research included a sociodemographic questionnaire and sport frequency identification part, followed by the use of other test standardised methods. The set of questionnaires consisted of two measuring methods - the one for spirituality measuring and the second for irrational beliefs. The spiritual structure and the level of spirituality have been identified with The Expressions of Spiritual Inventory - Revised - ESI-R (MacDonald, 2000), which is a 32-item self-report questionnaire that is designed to measure a five dimensional model of spirituality - cognitive orientation toward spirituality, experiential phenomenological dimension, existential well-being, paranormal beliefs, and religiousness, whereas thirty of items equally divided across spirituality dimensions and two items as measures of face validity and response honesty. The ESI-R uses a 5 -point Likert response scale $(0=$ strongly disagree, $1=$ disagree, $2=$ neutral, 3 = agree, $4=$ strongly agree) for respondents to rate the extent to which they agree with the items as being applicable to themselves. This scale was verified for Slovak health population by Michal Stríženec $(2004,2005)$. The Scale of Irrational Beliefs - IPA (Kondáš \& Kordáčová, 2000) is a response original Slovak scale of the Likert type, which captures the level of irrational type beliefs. This scale was applicated and based on Rational Emotive Behaviour Theory of Albert Ellis (Kondáš \& Kordáčová, 2000). The scale consists of 40 items, where the respondent chooses on a 5 -point scale the relevant answer $(0=$ strongly disagree, $1=$ disagree, $2=$ neutral, $3=$ agree, $4=$ strongly agree). This scale consists of 5 factors - helplessness, idealisation, perfectionism, external vulnerability, and negative expectations. This scale was selected to determinate the level of irrational beliefs in health population. During the evaluation of the results, we worked with the total achieved score.

\section{Statistical analysis}

Descriptive statistics were used to give an indicator of mean scores on subscales of spirituality and irrational beliefs in health Slovak and Czech population. The study used the correlation research design, whereby we analysed the frequency of particular item and correlations by means of correlation analysis between cardinal variables using Pearson coefficient representing the linear dependence between the two variables which is used in the normal distribution of data. The tightness of relationship was assessed for $5 \%$ and $1 \%$ of the level of statistical significance. Data were collected anonymously and evaluated using a statistical program SPPS (Version 23 for Windows, IBM, Armonk, NY, USA).

\section{RESULTS}

The basic descriptive characteristics - mean, standard deviation, minimum and maximum score value achieved by the Slovak and Czech health population in the questionnaire ESI-R (MacDonald, 2000) and in the scale IPA 
Table 1

Descriptive statistics of spirituality (ESI-R) and irrational beliefs (IPA) based on sport frequency in Slovak and Czech health population

\begin{tabular}{|c|c|c|c|c|c|c|c|}
\hline Scale & Variable & $\begin{array}{c}\text { Sport } \\
\text { frequency }\end{array}$ & $\mathrm{N}$ & M & SD & Min & $\operatorname{Max}$ \\
\hline \multirow{20}{*}{$E S I-R$} & \multirow{4}{*}{ COS } & non-athletes & 49 & 17.24 & 5.97 & 1 & 24 \\
\hline & & casual & 194 & 17.80 & 5.03 & 4 & 24 \\
\hline & & regular & 110 & 16.69 & 5.37 & 0 & 24 \\
\hline & & professional & 116 & 18.63 & 5.41 & 0 & 24 \\
\hline & \multirow{4}{*}{ EPD } & non-athletes & 49 & 9.89 & 5.41 & 0 & 20 \\
\hline & & casual & 194 & 11.09 & 5.88 & 0 & 24 \\
\hline & & regular & 110 & 11.32 & 6.86 & 0 & 24 \\
\hline & & professional & 116 & 13.08 & 6.72 & 0 & 24 \\
\hline & \multirow{4}{*}{ EWB } & non-athletes & 49 & 13.67 & 3.28 & 5 & 20 \\
\hline & & casual & 194 & 14.20 & 3.74 & 1 & 24 \\
\hline & & regular & 110 & 15.69 & 3.44 & 4 & 20 \\
\hline & & professional & 116 & 8.93 & 4.17 & 3 & 20 \\
\hline & \multirow{4}{*}{ PAR } & non-athletes & 49 & 9.18 & 3.49 & 1 & 15 \\
\hline & & casual & 194 & 10.62 & 4.12 & 0 & 22 \\
\hline & & regular & 110 & 11.54 & 4.01 & 0 & 23 \\
\hline & & professional & 116 & 12.00 & 2.64 & 10 & 15 \\
\hline & \multirow{4}{*}{ REL } & non-athletes & 49 & 15.85 & 6.97 & 0 & 24 \\
\hline & & casual & 194 & 16.17 & 5.93 & 0 & 24 \\
\hline & & regular & 110 & 14.07 & 6.33 & 0 & 23 \\
\hline & & professional & 116 & 16.34 & 6.16 & 0 & 23 \\
\hline \multirow{20}{*}{$E P I$} & \multirow{4}{*}{ HL } & non-athletes & 49 & 21.79 & 6.57 & 11 & 37 \\
\hline & & casual & 194 & 20.80 & 6.86 & 10 & 44 \\
\hline & & regular & 110 & 21.40 & 5.93 & 10 & 40 \\
\hline & & professional & 116 & 20.05 & 6.10 & 10 & 40 \\
\hline & \multirow{4}{*}{ ID } & non-athletes & 49 & 23.10 & 5.59 & 10 & 33 \\
\hline & & casual & 194 & 23.11 & 4.99 & 8 & 37 \\
\hline & & regular & 110 & 22.20 & 4.87 & 8 & 33 \\
\hline & & professional & 116 & 22.46 & 4.24 & 11 & 33 \\
\hline & \multirow{4}{*}{ PE } & non-athletes & 49 & 18.12 & 5.25 & 9 & 33 \\
\hline & & casual & 194 & 17.73 & 4.84 & 8 & 33 \\
\hline & & regular & 110 & 17.77 & 5.09 & 8 & 30 \\
\hline & & professional & 116 & 19.05 & 5.00 & 8 & 29 \\
\hline & \multirow{4}{*}{ EV } & non-athletes & 49 & 27.51 & 5.42 & 15 & 39 \\
\hline & & casual & 194 & 28.72 & 6.44 & 10 & 43 \\
\hline & & regular & 110 & 28.30 & 6.50 & 10 & 43 \\
\hline & & professional & 116 & 29.26 & 5.66 & 13 & 43 \\
\hline & \multirow{4}{*}{$\mathrm{NE}$} & non-athletes & 49 & 17.06 & 4.36 & 10 & 26 \\
\hline & & casual & 194 & 17.27 & 4.75 & 7 & 30 \\
\hline & & regular & 110 & 16.37 & 5.13 & 7 & 22 \\
\hline & & professional & 116 & 15.06 & 4.65 & 7 & 29 \\
\hline
\end{tabular}

Source: own research 
(Kondáš \& Kordáčová, 2000), and are presented in Table 1. Subsequently, in Table 2 we present the results of correlation analysis between the spirituality dimensions - cognitive orientation toward spirituality (COS), experiential phenomenological dimension (EPD), existential well-being (EWB), paranormal beliefs (PAR), and religiousness (REL) of health population and their irrational belief - helplessness (HL), idealisation (ID), perfectionism (PE), external vulnerability (EV), and negative expectations (NE). The Cronbach coefficient alphas observed in our study - ESI-R: COS $-\alpha=.656, \mathrm{EPD}-\mathrm{a}=$ $.681, \mathrm{EWB}-\mathrm{a}=.640, \mathrm{PAR}-\mathrm{a}=.659, \mathrm{REL}-\mathrm{a}=.666$; EPI: $\mathrm{HL}-\mathrm{a}=.628, \mathrm{ID}-\mathrm{a}$ $=.615, \mathrm{PE}-\mathrm{a}=.598, \mathrm{EV}-\mathrm{a}=.609$, and NE $-\mathrm{a}=.614-$ ensure the reliability of these inventories for a particular dataset.

Table 2

Results of correlation analysis between ESI-R and IPA

\begin{tabular}{cccccccc}
\hline Scale & & \multicolumn{7}{c}{ IPA } \\
\cline { 2 - 8 } & Variables & total score & HL & ID & PE & EV & NE \\
\hline ESI-R & COS & $-.209^{* *}$ & $-.318^{* *}$ & $-.101^{*}$ & -.087 & -.059 & $-.230^{* *}$ \\
\cline { 2 - 7 } & $-.203^{* *}$ & $-.277^{* *}$ & $-.162^{* *}$ & -.027 & $-.124^{* *}$ & $-.176^{* *}$ \\
\cline { 2 - 7 } & EPD & $-.134^{* *}$ & -.072 & -.074 & $-.135^{* *}$ & $-.170^{* *}$ & -.061 \\
\cline { 2 - 7 } & EWB & .037 & .025 & .041 & $.096^{*}$ & -.062 & .071 \\
\cline { 2 - 7 } & PAR & $-.137^{* *}$ & $-.237^{* *}$ & -.060 & -.026 & -.014 & $-.182^{* *}$ \\
\hline & REL & $-.215^{* *}$ & $-.300^{* *}$ & $-.122^{* *}$ & -.059 & $-.130^{* *}$ & $-.201^{* *}$ \\
\hline
\end{tabular}

${ }^{*} p<.05,{ }^{* *} p<.01$

Source: own research

In Table 1, in the variable of spirituality we can identify significantly higher score in the group of professional athletes in all scales except EWB. In the variable of irrational beliefs we found a difference between groups in the scale of PE, and EV - higher mean of score in group of professional athletes - and in the scale of NE - lower mean of score in the same group. As seen in Table 2, there are significant negative relationships between the spirituality and irrational beliefs. A significant negative correlation was found between several spirituality scales - COS $(r=-.209)$, EPD $(r=-.203)$, EWB ( $r$ $=-.134)$, and REL ( $r=-.137)$. Only in case of the PAR $(r=.037)$ scale of spirituality there are some finding in positive direction. The correlation between variables in total score is also in negative direction $(r=-.215)$ at the level of significance $p<.01$. From the point of view of irrational beliefs, the highest rate of negative correlation with spirituality in total score we can find in scale of HL $(r=-.300)$, also in scale of NE $(r=-.201)$. The correlation in total score of spirituality with EV $(r=-.130)$ and ID $(r=-.122)$ is also significant at the level $\mathrm{p}<.01$. In the scale of PE we can see the correlation with EWB $(r=-.135)$, and with PAR $(r=.096)$. 


\section{DISCUSION}

In the first part of our research we try to answer the research question if there are differences in spirituality and irrational beliefs based on frequency of sports activity. In all scale exclude existential well-being (EWB) we can find higher level of answering score in the group of professional athletes. These results are applicable to the concept of non-religious spirituality in sport psychology (Ridley, 1996).

In the second part of our research, we focused on relationship and results of correlation analysis between spirituality - measured by ESI-R (MacDonald, 2000), and irrational beliefs - measured by IPA (Kondáš \& Kordáčová, 2000). The spirituality inventory used in our research confirmed the negative correlation with irrational beliefs in four scales - COS (cognitive orientation), EPD (experiential phenomenologist), EWB (existential well-being), and REL (religiousness). The highest negative value of correlation with irrational beliefs was reached by the relationship between cognitive orientation toward spirituality $\left(\mathrm{r}=-.209^{* *}\right)$ and experiential phenomenological dimension $(\mathrm{r}=$ $\left.-.203^{* *}\right)$.

There is positive correlation in only one case, and it is scale of paranormal beliefs (PAR). In this case the paranormal beliefs are characterised by belief in extrasensory perception, transmission of thoughts, witches and ghosts. We expected a positive correlation with irrational thinking in this section.

Our examination turned out to have several limitations. The method of obtaining research sample participants may be questioned due to the purposeful acquisition of research persons. The issue of relevance of our statements can also partially lie in the motivation of the research participants, which might have been influenced by online testing form and the duration of the measurement tools. We recommend using our result as the basis for the hypotheses of next research studies in order to confirm our findings.

\section{CONCLUSIONS}

In our study, we focused on the correlations between irrational beliefs and spirituality in group of Slovak and Czech population. Based on our results we can draw several conclusions. Research results confirmed the differences between the variables of spirituality and irrational beliefs based on the frequency of sports activities. Our findings confirmed the relationships between the variables - spirituality and irrational beliefs. The results can help performance coaches and sport psychologist better understand the situation-related aspects of human beliefs in situation of failure or the way to defend onefrom defeat in rational way. Also, this information can be used to advice problems of motivation loss, locus of control, and realistic belief in sport competition. 


\section{FUNDING}

This paper is published within the frame of the project Institutional Counselling in Fight against Discrimination (ITMS2014 + 312041V753). This project is implemented thanks to support from the European Social Fund and the European Regional Development Fund under the Operational Program Human Resources and with the support of International Scientific Research Project: Pastoral practice, psychology and philosophical-theological-social fragments in the light of the 21st century (contract number: 010-2021). Cooperation among: Sociedad Hispánica de Amigos de Kierkegaard, University of Granada (Spain) and College of Applied Psychology in Terezín (Czech Republic), 2021-2022.

There was no conflict of interest.

\section{RERERENCES}

[1] Adamovová, L. (2005). Implicit theories of religious fundamentalism among Slovak young adults. Studia Psychologica, 47(3), 235-246.

[2] Adamovová, L., \& Halama, P. (2009). Vztáhová väzba a religiozita [Attachment and religionisity]. Bratislava: Slovak Academic Press.

[3] Adamovová, L., \& Kordačová, J. (2002). Iracionalita ako aspekt náboženského fundamentalizmu [Irrationality as an aspect of religious fundamentalism]. In: D. Kováč (Ed.), Psychologické sondy do problematiky spirituality [Psychological probes into the issue of spirituality] (pp. 39-48). Bratislava: Inštitút experimentálne psychológie SAV.

[4] Alaverdov, E. (2021). Modern migration crisis in Europe and the role of diasporas in combating the mutual hostility between newcomers and host society. Journal of Education Culture and Society 12(1), 177-186. https:/ / doi.org/10.15503/Jecs2021.1.177.186

[5] Bednář, M. (2009). Pohyb člověka na biodromu: Cesta životem z pohledu (nejen) kinantropologie [Human movement on the biodrome: The journey through life from the point of view of (not only) kinanthropology]. Praha: Karolinum.

[6] Binetti, M. J., Králik, R., Tkáčová, H., \& Roubalová, M. (2021). Same and other: from Plato to Kierkegaard. A reading of a metaphysical thesis in an existential key. Journal of Education Culture and Society, 12(1), 15-31. https:// doi.org/10.15503/jecs2021.1.15.31.

[7] Brent, J. (1994). Leaving protestant fundamentalism: a qualitative analysis of a major life transition. Counseling and Values, 38(3), 205-215.

[8] Brod'áni, J. (2012). Sport activity level and the life quality of adolescents. Acta Universitatis Matthiae Belii, Physical Education and Sport, 4(1), 21-30.

[9] Haag, H., \& Paas, M. (1992). Cooperation of sport and church (example: Catholic church of Germany). International Journal of Physical Education, 29(2), 40-41.

[10] Halama, P., Adamovová, L., Hatoková, M., \& Stríženec, M. (2006). Religiozita, spiritualita a osobnost: vybrané kapitoly z psychológie náboženstva [Religiosity, spirituality and personality: Selected chapters from the psychology of religion]. Bratislava: Ústav experimentálnej psychológie SAV.

[11] Hassan, S. (1994). Jak čelit psychické manipulaci zhoubných kultu[How to face the psychological manipulation of malignant cult]. Brno: Nakladatelství Tomáše Janečka.

[12] Hoffman, S. (1999). The decline of civility and the rise of religion in American sport. Quest, $51,69-84$.

[13] Hurych, E. (2013). Spiritualita pohybových aktivit [Spirituality of physical activities]. Brno: Masarykova univerzita.

[14] Jirásek, I. (2008). Hra jako průnik sakrálního a profánního (Game as an intersection of sacred and profane). In: L. Charvát (Ed.), Hry 2008: sborník př̌spěvků s tématikou her v programech tělovýchovných procesů [Games 2008: Collection of papers on the topic of games in the programmes of physical education processes] (pp. 120-124). Plzeň: Katedra tělesné a sportovní výchovy Západočeské university. 
[15] Jirásek, I. (2010). The forgotten paradigm: Spirituality of games and play. In: A. Hardman \& C. Jones (Eds.), Philosophy of sport: International perspectives (pp. 72-83). Newcastle upon Tyne, UK: Cambridge Scholars Publishing.

[16] Jirásek, I. (2011). Pilgrimage as a form of physical and movement spirituality. In: J. Parry, M. Nesti \& N. Watson (Eds.), Theology, ethics and transcendence in sports (pp. 223-232). New York, US: Routledge.

[17] Jirásek, I. (2015). Religion, spirituality, and sport: from religio athletae toward spiritus athletae, Quest, 67(3), 290-299.

[18] Johnson, W. (1992). Rational-emotive therapy and religiousness: A review. Journal of RationalEmotive and Cognitive-Behaviour Therapy, 10(1), 21-35.

[19] Kahan, D. (2002). Religiosity as a determinant of physical activity: The case of Judaism. Quest, 54, 97-115.

[20] Kirkpatrick, L., Hood, R., \& Hartz, G. (1991). Fundamentalist religion conceptualised in terms of Rokeach's theory of the open and closed mind. Journal for the Social Scientific Study of Religion, 3, 157-179.

[21] Kobylarek, A. (2016). Preface: Levels of resentment in the University of the Third Age. Journal of Education Culture and Society, 7(1), 5-8. https:/ / doi.org/10.15503/jecs20161.5.8

[22] Kondáš, O., \& Kordáčová, J. (2000). Iracionalita a jej hodnotenie: Sme iracionálni? A do akej miery? [Irrationality and its evaluation: Are we irrational? And to what extent?] Bratislava: Stimul.

[23] Králik, R (2013a). Marie Mikulova Thulstrup (1923-2013) and her work. Filosofický časopis, 61(3), 439-442.

[24] Králik, R. (2013b). The reception of Soren Kierkegaard in Czech language writings. Filosofický časopis, 61(3), 43-451.

[25] Králik, R., \& Pavlíková, M. (2013). The reception of Kierkegaard’s thought in Slovakia 2013. Filozofia, 68(1), 82-86.

[26] Lacombe, P. (2001). The Breton body in culture and religion. Culture, Sport, Society, 4(3), 27-48.

[27] Lawrence, C. (1987). Rational-emotive therapy and the religious client. Journal of RationalEmotive Therapy, 5(1), 13-21.

[28] Lišková, R., \& Jirásek, I. (2013). Specifičnost pohybu ve vodním prostředí z hlediska spirituality [Specificity of movement in the aquatic environment in terms of spirituality]. Tělesná kultura, 36(2), 9-20.

[29] MacDonald, D., \& Kirk, D. (1999) Pedagogy, the body and Christian identity. Sport, Education and Society, 4(2), 131-142.

[30] Nemec, M. (2010). Agonistika a názorový pluralizmus gréckych antických autorov [Agonistics and pluralism of opinion of Greek ancient authors]. Telesná výchova a šport, 20(4), 6-10.

[31] Nielsen, L. (1994). Rational-emotive behaviour therapy and religion: do not throw the therapeutic baby out with the holy water! Journal of Psychology and Christianity, 13(4), 312-322.

[32] Oborný, J. (2015). Filozofia a šport [Philosophy and sport]. Bratislava: Univerzita Komenského.

[33] Parry, J., Robinson, S., Watson, N., \& Nesti, M. (2007). Sport and spirituality. An introduction. London, UK: Routledge.

[34] Preece, G., \& Hess, R. (Eds.). (2006). Sport and spirituality: An exercise in everyday theology. Interface: A forum for theology in the world. Adelaide, Australia: ATF Press.

[35] Ridley, M. (1996). The origins of virtue. London, UK: Penguin Books.

[36] Ridley, M. (2000). O pưvodu ctnosti: O evolučních základech a zákonitostech nesobeckého jednání člověka [On the origin of virtue: On the evolutionary foundations and laws of unselfish human behaviour]. Praha: Portál.

[37] Rife, J., \& Lester, D. (1997). Religiosity and psychological disturbance. Psychological Reports, $81,978$.

[38] Robinson, S., \& Parry, J. (2013). Spiritualita: K otázce definice [Spirituality: On the question of definition]. In: E. Hurich et al. (Eds.), Spiritualita pohybových aktivít (pp. 17-28). Brno: Masarykova univerzita (Masaryk University).

[39] Tkáčová, H. (2021). Forms of prejudice about Christians and social cohesion between university students in Slovakia: Media as an essential part of the issue. Journal of Education Culture and Society, 12(1), 429-444. 
[40] Tkáčová, H., Al-Absiová, E., Al-Absi, M., \& Pavlíková, M. (2021). "Media invasion": Against Islam in the context of the Slovak Republic. Media Literacy and Academic Research, 4(1), 165-179.

[41] Tkáčová, H., Pavlíková, M., Tvrdoň, M., \& Prokopyev, A. I. (2021). Existence and prevention of social exclusion of religious university students due to stereotyping. Bogoslovni vestnik / Theological Quarterly, 81(1), 199-223. https:/ / doi.org/10.34291/BV2021/01/Tkacova

[42] Tomanová Čerget'ová, I. (2008). Vzt'ahová väzba a iracionalita ako prediktory prosociálnych tendenciú [Attachment and irrationality as predictors of prosocial tendencies]. In: M. Danková \& Z. Zhullnerová. Zborník z 2. ročníka sút’aže o najlepšiu diplomovú alebo ročníkovú prácu na tému filantropia. Bratislava: Centrum pre filantropiu.

[43] Žalec, B., \& Pavlíková, M. (2019a). Religious tolerance and intolerance. European Journal of Science and Theology, 15(5), 39-48.

[44] Žalec, B., \& Pavlíková, M. (2019b). Civis virtues and functions of religion in public life. European Journal of Science and Theology, 15(6), 75-84. 